\title{
Astrocyte elevated gene- 1 is associated with metastasis in head and neck squamous cell carcinoma through p65 phosphorylation and upregulation of MMP1
}

\author{
Yi-Ping Wang ${ }^{1,2,3}$, I-Ju Liu' ${ }^{2}$ Chiung-Pin Chiang ${ }^{3,4}$ and Han-Chung Wu $\mathbf{u}^{2,4^{*}}$
}

\begin{abstract}
Background: The survival rate of head and neck squamous cell carcinoma (HNSCC) at advanced stage is poor, despite contemporary advances in treatment modalities. Recent studies have indicated that astrocyte elevated gene-1 (AEG-1), a single transmembrane protein without any known functional domains, is overexpressed in various malignancies and is implicated in both distant metastasis and poor survival.

Results: High expression of AEG-1 in HNSCC was positively correlated with regional lymph node metastasis and a poor 5-year survival rate. Knockdown of AEG-1 in HNSCC cell lines reduced their capacity for colony formation, migration and invasion. Furthermore, decreased tumor volume and metastatic foci were observed after knockdown of AEG-1 in subcutaneous xenografts and pulmonary metastasis assays in vivo, respectively. We also demonstrated that AEG-1 increased phosphorylation of the p65 subunit of NF-KB, and regulated the expression of MMP1 in HNSCC cells. Moreover, compromised phosphorylation of the p65 (RelA) subunit of NF-KB at serine 536 was observed upon silencing of AEG-1 in both HNSCC cell lines and clinical specimens.
\end{abstract}

Conclusion: High expression of AEG-1 is associated with lymph node metastasis and its potentially associated mechanism is investigated.

Keywords: Astrocyte elevated gene-1 (AEG-1), Head and neck squamous cell carcinoma (HNSCC), Metastasis, Matrix metalloproteinase 1 (MMP1), p65

\section{Background}

Head and neck squamous cell carcinoma (HNSCC) poses a grave threat to public health in Melanesia, South-Central Asia, and Central and Eastern Europe, with 263,900 new cases and 128,000 HNSCC related deaths reported worldwide annually [1]. This cancer usually arises within the mucosa lining the upper aerodigestive tract, with oral cavity, oropharynx, hypopharynx and larynx being the four most common affected sites. Regional lymph node metastasis, which is a common feature, is present in approximately two thirds of patients with advanced stage HNSCC. Increased

\footnotetext{
* Correspondence: hcw0928@gate.sinica.edu.tw

${ }^{2}$ Institute of Cellular and Organismic Biology, Academia Sinica, Taipei, Taiwan ${ }^{4}$ Graduate Institute of Oral Biology, School of Dentistry, National Taiwan University, Taipei, Taiwan

Full list of author information is available at the end of the article
}

number of lymph nodes with metastatic lesions and the presence of extranodal spread are strong predictors for distant metastasis and poor survival of the patient [2]. Despite recent advances in oromaxillofacial surgery and combination treatment using either EGFR-targeting antibodies or tyrosine kinase inhibitors, there has been little improvement in the survival of patients with metastatic HNSCC [3-5]. As such, there is an urgent need to identify new predictive parameters for lymph node metastasis and novel therapeutic targets for HNSCC.

Astrocyte elevated gene-1 (AEG-1), also known as metadherin (MTDH) or LYsine-RIch CEACAM1 coisolated (LYRIC), is a 582 amino acid residues type II transmembrane protein without any known functional domains. It has emerged as a novel oncoprotein essential for malignant progression in various types of human 
cancers [6-13]. The amino acid sequence of AEG-1 possesses three nuclear localization signals, and ubiquitination of AEG-1 determines the subcellular region to which it is transported [14] through an as yet undelineated mechanism. Brown et al. used phage display to identify AEG-1 as a receptor that mediates adhesion of murine mammary tumor cells to lung endothelial cells and promotes lung metastasis [15]. Membranous AEG-1 has been shown to enhance adhesion of tumor cells to pulmonary microvascular endothelial cells [9]. The major signaling cascades activated by AEG-1 are the PI3K and NF- $\mathrm{kB}$ pathways, [6,16,17] and AEG-1 has recently been proposed to physically interact with AP1, SND-1, and the p65 subunit of NF-кB [18-20]. However, the direct effects on the associated proteins after the binding of AEG-1 remain unclear. Expression of AEG-1 is increased by TNF- $\alpha$ and $\mathrm{HIV}$ infection in astrocytes, whereas microRNA-375 (miR375) is a negative regulator of AEG-1 [13,21,22]. Mounting evidence suggests that AEG-1 confers pleiotrophic aggressive phenotypes in malignant neoplasms, especially with respect to invasion and metastasis. Nonetheless, the definitive link between the expression of AEG1 and its prognostic value in HNSCC patients still needs to be established with a large cohort of clinical specimen, while its underlying molecular mechanisms need to be elucidated. Since the presence of metastatic lesions has a negative impact on the prognosis and morbidity of HNSCC patients, it prompts us to investigate the biological role of AEG-1 in this disease entity.

In the current article, we report that AEG-1 is overexpressed in a majority of clinical specimens of oral squamous cell carcinoma (OSCC, a subset of HNSCC), and its expression is positively associated with both the presence and the degree of lymph node metastasis. Knockdown of AEG-1 also decreases the aggressiveness of HNSCC cell lines both in vitro and in vivo. As far as we know, this is the first study to demonstrate that AEG-1 modulates the phosphorylation at serine 536 of the p65 subunit of NF- $\mathrm{kB}$ in HNSCC, which in turn regulates the production of MMP1 by manipulating the binding of NF- $\mathrm{kB}$ to its promoter region.

\section{Results}

High AEG-1 expression in OSCC is associated with regional lymph node metastasis and unfavorable 5-year survival

Immunohistochemical analysis of AEG-1 revealed high expression of AEG-1 in 40.86\% (38 out of 93) of examined OSCC clinical specimens. AEG-1 was primarily located in the cytoplasm (the perinuclear region, in particular) of the neoplastic cells, and focal nuclear stains were also observed. In tumors with low AEG-1 expression, the majority of AEG-1-positive cells were found at the peripheral cells of the tumor nests, and not in the more-differentiated malignant cells (Figure 1A). In addition, no positive signal of AEG-1 was discerned in all 30 cases of uninflamed normal oral mucosa. Of the clinical parameters examined, late clinical stage $(p=0.01)$ and positive regional nodal metastasis $(p<0.001)$ were found to be significantly correlated to AEG-1 expression (Table 1). Futhermore, advanced lymph node metastasis (N2 and N3) is more common in the high AEG-1-expressing group ( $p=0.012$, Additional file 1: Table S1). The incidence of distant metastasis was also elevated (albeit not significantly) in the high AEG-1 -expressing group, as compared to that in the low and nil AEG-1-expressing groups (10.53\% and $1.83 \%$, respectively). Furthermore, a statistically significant reduction in the 5-year disease-specific survival rate was observed in the high AEG-1-expressing group as compared to that in the low and nil AEG-1-expressing groups (36.84\% versus $69.09 \%$, log-rank test $p=0.0014$, Figure 1B). These results imply that AEG-1 is associated with metastasis of OSCC and may serve as a negative prognostic factor for survival.

\section{AEG-1 knockdown reduced the aggressiveness of HNSCC cell lines in vitro}

To establish an in vitro platform for elucidation of the biological function of AEG-1 in HNSCC cell lines, we examined the expression status of AEG-1 in several cell lines generated from HNSCC. Western blots revealed that AEG-1 was ubiquitously expressed in all HNSCC cell lines tested (Figure 1C). We subsequently generated stable clones of SAS and FaDu cells expressing AEG-1shRNA-B, in which AEG-1 mRNA and protein are efficiently suppressed (SB cells and FB cells, respectively; Additional file 2: Figure S1). Although marginal inhibition of cellular proliferation was observed after knockdown of AEG-1 in SB cells, FB cells demonstrated remarkable reduction in proliferation $(77.39 \%, p=0.056$ and $57.07 \%, p<0.001$ on average as compared to the corresponding control, respectively, by day 4 after seeding, Figure 2A). A dramatic reduction of colonies was also observed in both SB and FB cells, as compared to that in the relevant control (77 versus 165 colonies and 48 versus 215 colonies on average for the SAS groups and FaDu groups, respectively, Figure 2B). Delayed wound healing and reduced Matrigel penetration were observed in AEG-1 knockdown cells (Figures 2C and $D$, respectively). At 12 hours after removal of the inserts, cells covered $96.9 \%$ of the visualized field area in the SCt group, but only $74.5 \%$ in the SB group (66\% and $64.4 \%$ at the initial time point, respectively, Figure $2 \mathrm{C}$ ). For the FaDu group at 12 hours, $85.9 \%$ and $78.5 \%$ of the areas were occupied by FCt and FB cells, respectively (initial, $70.8 \%$ and $70.1 \%$, Figure 2C). The number of penetrated cells in AEG-1 knockdown cells was about 


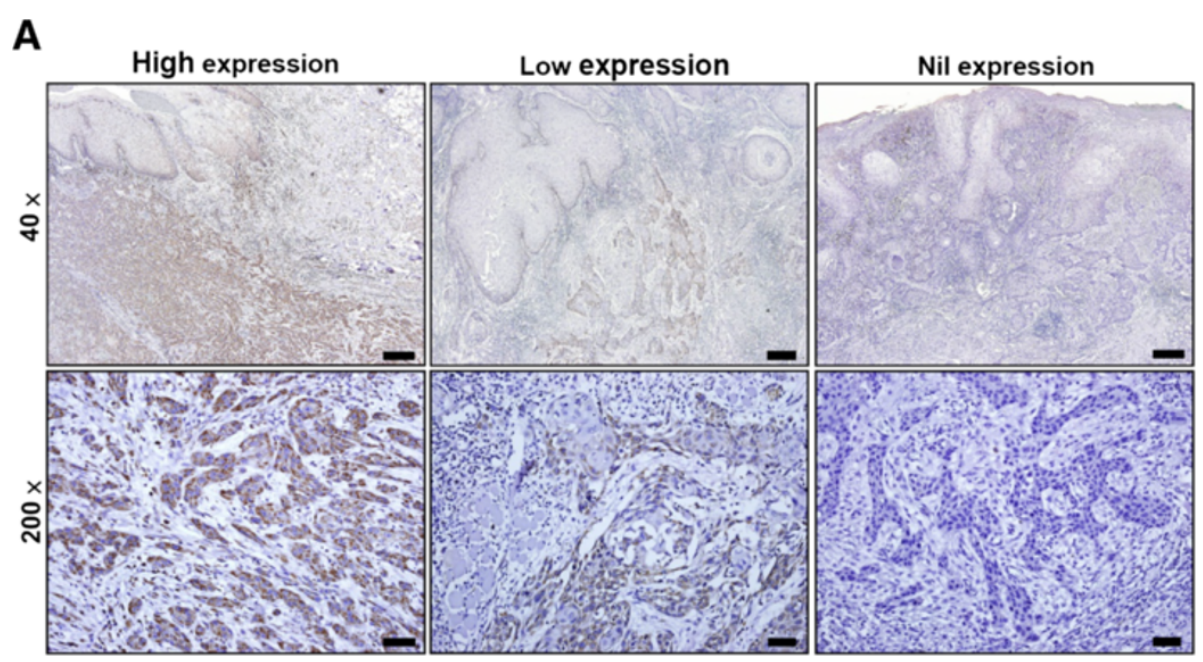

B

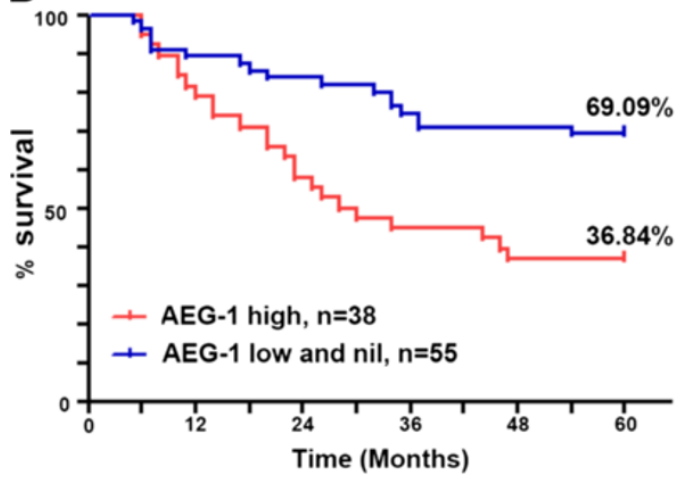

C

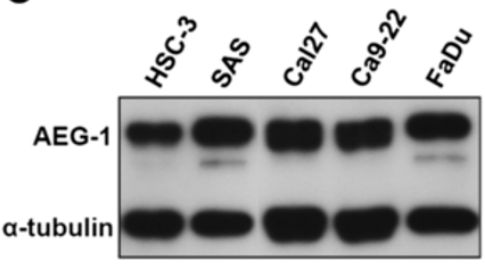

Figure 1 AEG-1 expression in clinical specimens of OSCC and cell lines of HNSCC. (A) immunohistochemical staining of formalin-fixed, paraffin embedded OSCC specimens. Scale bar: $40 \times, 300 \mu \mathrm{m} ; 200 \times, 45 \mu \mathrm{m}$. (B) Kaplan-Meier 5-year survival analysis of 93 cases of OSCC segregated by expression status of AEG-1 protein. (C) AEG-1 protein expression in HNSCC cell lines.

$10 \%$ of the relevant control, for both SAS and FaDu cells (Figure 2D). These observations suggest that AEG-1 contributes to aggressive phenotypes of HNSCC cells, particularly with regards to their migration and invasion capacities.

\section{AEG-1 knockdown reduces tumor volume and pulmonary metastatic nodules of HNSCC cell lines in vivo}

To evaluate the biological impact of AEG-1 knockdown on HNSCC cell lines in vivo, subcutaneous xenografts were implanted into the flanks of Nod/SCID mice. Consistent with the results acquired in vitro, the volume of tumors arising from AEG-1-knockdown cells was smaller than those arising from the relevant control cells at all time points examined, with the suppression effect being more evident in $\mathrm{FaDu}$ cell lines (394.99 versus $714.71 \mathrm{~mm}^{3}$ in the SAS group and 207.70 versus $1314.33 \mathrm{~mm}^{3}$ in the $\mathrm{FaDu}$ group at the end point, Figure $3 \mathrm{~A})$. The tumor weight at the end-point of the experiment was also decreased in the AEG-1-knockdown groups as compared to that in the control groups
(Figure 3B). Histopathological examination of harvested xenografts revealed infiltrating invasion fronts in a pattern of discrete cell nests in four out of six tumors from SCt cells and in three out of six tumors from FCt cells (Figure 3C). However, all xenografts from SB and FB cells assumed an expansile pattern of growth. Furthermore, perineural encroachment by the tumor cells was evident in two xenografts from the SCt cells. The numbers of pulmonary metastatic foci in the AEG-1-knockdown groups were also remarkably less than those of the corresponding control groups, and the size of the metastatic foci from SB cells was smaller than those observed in the SCt group (Figure 3D). These in vivo observations are consistent with the findings in clinical specimens and further support the hypothesis that AEG-1 is involved in the metastatic cascade of HNSCC.

\section{AEG-1 suppression downregulates MMP1 production}

To determine the downstream targets of AEG-1 that contribute to invasion and metastasis pathways in HNSCC cells, we performed a microarray comparison 
Table 1 Clinicopathological correlation with AEG-1 in 93 cases of OSCC

\begin{tabular}{|c|c|c|c|}
\hline \multirow[t]{3}{*}{ Parameter } & \multicolumn{2}{|c|}{ AEG-1 expression status } & \multirow{3}{*}{$\begin{array}{l}\text { Fisher's } \\
\text { exact test } \\
p \text { value }\end{array}$} \\
\hline & Low & High & \\
\hline & No. (\%) & No. (\%) & \\
\hline \multicolumn{4}{|l|}{ Gender } \\
\hline Male & $46(83.64 \%)$ & $33(86.84 \%)$ & \multirow[t]{2}{*}{0.773} \\
\hline Female & $9(16.36 \%)$ & $5(13.16 \%)$ & \\
\hline \multicolumn{4}{|l|}{ Age } \\
\hline$>50 \mathrm{y} / \mathrm{o}$ & $36(65.45 \%)$ & $20(52.63 \%)$ & \multirow[t]{2}{*}{0.282} \\
\hline$<50 \mathrm{y} / \mathrm{o}$ & 19 (34.55\%) & $18(47.37 \%)$ & \\
\hline
\end{tabular}

\section{Location}

\begin{tabular}{|c|c|c|c|}
\hline Buccal mucosa & $22(40.00 \%)$ & $18(47.37 \%)$ & 0.307 \\
\hline Gingiva & $11(20.00 \%)$ & $3(7.89 \%)$ & \\
\hline Floor of the mouth & 1 (1.81\%) & 2 (5.26\%) & \\
\hline Lip & $0(0 \%)$ & $2(5.26 \%)$ & \\
\hline Tongue & $19(34.55 \%)$ & $12(31.58 \%)$ & \\
\hline Palate & $2(3.64 \%)$ & $1(2.64 \%)$ & \\
\hline \multicolumn{4}{|l|}{ Stage } \\
\hline $\mid+\|$ & $30(54.55 \%)$ & $10(26.32 \%)$ & 0.01 \\
\hline III+IV & $25(45.45 \%)$ & $28(73.68 \%)$ & \\
\hline
\end{tabular}

T

\begin{tabular}{|c|c|c|c|}
\hline $\mathrm{T} 1+\mathrm{T} 2$ & $31(56.36 \%)$ & 22 (57.89\%) & 1.000 \\
\hline $\mathrm{T} 3+\mathrm{T} 4$ & $24(43.64 \%)$ & $16(42.11 \%)$ & \\
\hline \multicolumn{4}{|l|}{$\mathrm{N}$} \\
\hline No & 47 (85.45\%) & 17 (44.74\%) & $<0.001$ \\
\hline $\mathrm{N} 1+\mathrm{N} 2+\mathrm{N} 3$ & $8(14.55 \%)$ & $21(55.26 \%)$ & \\
\hline \multicolumn{4}{|l|}{$\bar{M}$} \\
\hline MO & 54 (98.18\%) & 34 (89.47\%) & 0.155 \\
\hline M1 & $1(1.82 \%)$ & $4(10.53 \%)$ & \\
\hline
\end{tabular}

\begin{tabular}{|c|c|c|c|}
\hline Recurrence & & & \\
\hline Negative & $45(81.82 \%)$ & 30 (78.95\%) & 0.793 \\
\hline Positive & $10(18.18 \%)$ & $8(21.05 \%)$ & \\
\hline \multicolumn{4}{|l|}{ Differentiation } \\
\hline Well & $48(87.27 \%)$ & 27 (71.05\%) & 0.064 \\
\hline Moderate/poor & 7 (12.73\%) & 11 (28.95\%) & \\
\hline \multicolumn{4}{|l|}{ Alcohol } \\
\hline Negative & $24(43.64 \%)$ & 10 (26.32\%) & 0.125 \\
\hline Positive & 31 (56.36\%) & $28(73.68 \%)$ & \\
\hline \multicolumn{4}{|l|}{ Betel nut } \\
\hline Negative & 16 (29.09\%) & $6(15.79 \%)$ & 0.214 \\
\hline Positive & 39 (70.91\%) & 32 (84.21\%) & \\
\hline \multicolumn{4}{|l|}{ Cigarette } \\
\hline Negative & 14 (25.45\%) & $8(21.05 \%)$ & 0.805 \\
\hline Positive & 41 (74.55\%) & 30 (78.95\%) & \\
\hline
\end{tabular}

between the gene expression profiles of SB cells and SCt cells. The expression level of MMP1 (matrix metalloproteinase 1) in SB cells was downregulated by approximately 3.3 fold, as compared to that in SCt cells
(Figure 4A). RT-QPCR analysis also revealed a reduction in MMP1 mRNA in SB cells and FB cells (reduced to an average of $17.17 \%$ and $13.44 \%$ of the levels in the relevant controls, respectively, Figure 4B). In addition, AEG1 knockdown caused a remarkable reduction of secreted MMP1 protein in the cell-conditioned culture media for both SAS and FaDu cells (Figure 4C). Immunohistochemical staining of MMP1 revealed a reduced positive signal in tumor xenografts and pulmonary metastatic lesions generated from AEG-1-knockdown HNSCC cells, as compared to the cytosolic and juxtacellular staining of MMP1 observed in lesions arising from control cells (Figure 4D). Also, incorporation of MMP inhibitor I $(2 \mu \mathrm{M})$ hampered the invasion abilities of SAS and $\mathrm{FaDu}$ cells in transwell assays (Additional file 3: Figure S2). As MMPs are considered to be involved in both invasion and metastasis, MMP1 may be a downstream effector of AEG-1 in determining the aggressive phenotype of HNSCC.

\section{AEG-1 expression increases phosphorylation of the p65 subunit of NF-KB and enhances p65 binding to the MMP1 promoter}

We hypothesized that AEG-1 may affect MMP1 expression through NF- $\mathrm{kB}$ and $\mathrm{AP1}$, since the promoter of MMP1 harbors regulation sites for these two transcription factors. Western blotting revealed that the levels of the phosphorylated p65 subunit of NF- $\mathrm{kB}$ (serine 536) in SB cells and FB cells were $68.84 \%$ and $45.64 \%$ that of the control counterparts ( $p=0.013$ and $p=0.005$; $t$-test), respectively (Figure $5 \mathrm{~A}$ ). However, phosphorylation status of c-jun (a subunit of AP1), Akt and GSK3 $\beta$ (downstream targets of the PI3K pathway) were unaffected by AEG-1 knockdown (Additional file 4: Figure S3A). Also, the phosphorylation status of p65 at serine 468 and the level of phosphorylated ІкB are unchanged after AEG-1 knockdown in HNSCC cell lines (Additional file 4: Figure S3B). These observations prompted us to examine the relationship between AEG-1 expression and the phosphorylation status of p65 at serine 536 in clinical specimens of HNSCC. A spatial correlation between AEG-1 and phosphorylated p65 was evident in the high AEG-1-expressing group, while the phosphorylated p65 signals in the low and nil AEG-1-expressing cases were primarily observed at the peripheral basal cells of the neoplastic nests (the location of AEG-1 proteins, Figure 5B). AEG-1, phosphorylated p65 and MMP1 were co-localized in the enrolled cohort of OSCC, and these associations were statistically significant (Figure 5C). Moreover, high levels of both phosphorylated p65 (serine 536) and MMP1 in neoplastic cells were positively associated with advanced tumor stages, as well as with regional lymph node metastasis in OSCC (Additional files 5 and 6: Tables S2 and S3). High MMP1 expression was 
A

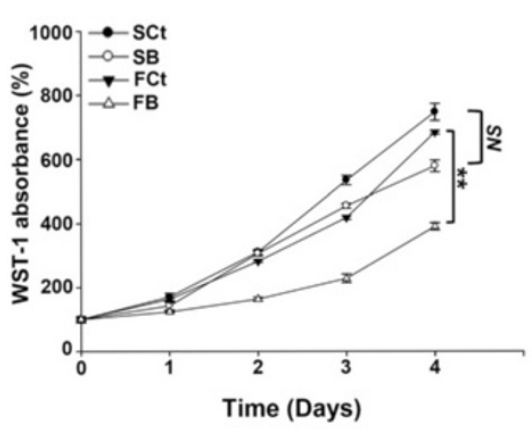

C

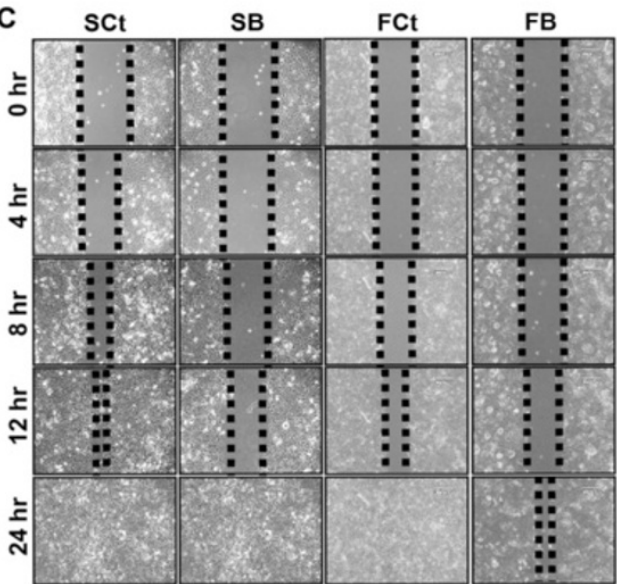

B

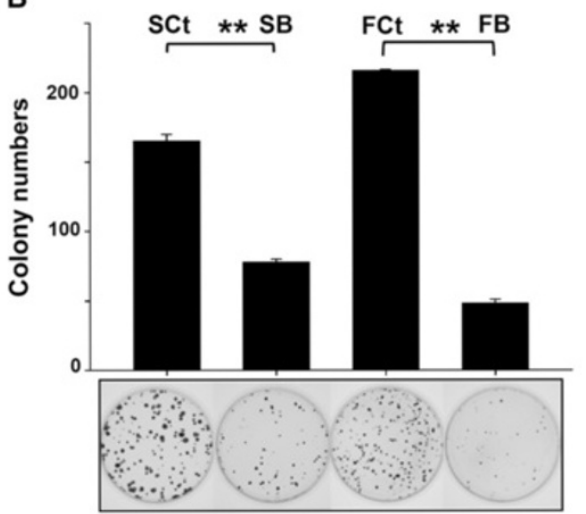

D

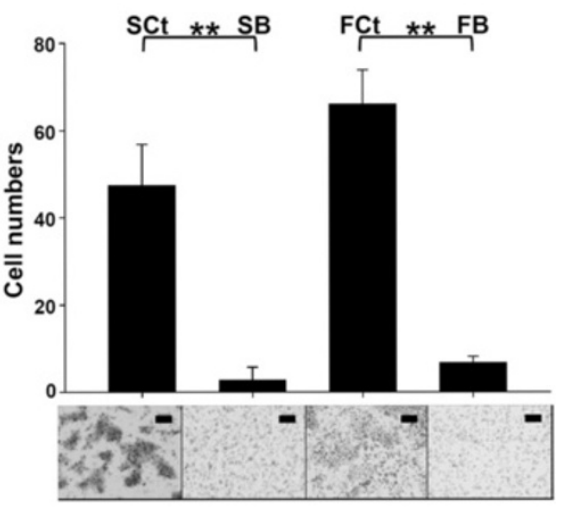

Figure 2 Impact of AEG-1 knockdown on the function of HNSCC cell lines. (A) WST-1 cell proliferation assay. (B) colony formation assay. (C) wound-healing migration assay. Initial gap: $500 \mu \mathrm{m}$. (D) transwell Matrigel invasion assay. All values are the average of three independent experiments. SB, AEG-1 knock-down SAS cells. FB, AEG-1 knock-down FaDu cells. SCt, SAS cells transfected with scrambled control shRNA. FCt, FaDu cells transfected with scrambled control shRNA. All data were expressed as mean $\pm \mathrm{SEM} ; \mathrm{n}=3$. NS, not significant $(p>0.05) ;{ }^{*}, p<0.01$. Scale Bar: $130 \mu \mathrm{m}$.

also significantly associated with distant metastasis in our samples (Additional file 6: Table S3).

Transmission electron microscopy revealed nuclear translocation of AEG-1 protein (Figure 6A), suggesting that AEG-1 may not be restricted to the membrane and cytosol, as previously reported. To further validate the hypothesis that AEG-1 regulates MMP1 through NF- $\mathrm{kB}$, we generated various luciferase reporter vectors driven by different fragments of the MMP1 promoter region (P1, -4372 to +52 ; P2, -2471 to +52 ; P3, -2269 to +52 ; and $\mathrm{P} 4,-521$ to +52 ) and transfected these reporters into the test cells (Figure 6B). A dramatic reduction of relative luciferase activity was observed in $\mathrm{SB}$ and $\mathrm{FB}$ cells transfected with $\mathrm{P} 1$ and P2, as compared to that in the respective controls; a smaller decrease was observed for knockdown cells transfected with P3, while luciferase activity was low in both knockdown and control cells transfected with P4 (Figure 6C). These results suggest that AEG-1 regulates elements between nucleo- tides -4372 to -2269 in the promoter of MMP1, where the binding sites of NF- $\mathrm{kB}$ and CBP are located. ChIP revealed that $\mathrm{AEG}-1, \mathrm{p} 65$ and $\mathrm{CBP}$ binding were reduced at the NF- $\mathrm{kB}$ binding sequence of the MMP1 promoter in $\mathrm{SB}$ and $\mathrm{FB}$ cells as compared to that in the relevant controls, consistent with the data from our luciferase assay (Figure 6D). Taken together, these data suggest that AEG-1 increases phosphorylation of the p65 subunit of NF- $\mathrm{kB}$ and regulates the expression of MMP1 in HNSCC cells.

\section{Discussion}

In this study, we found that high expression of AEG-1 was correlated with advanced tumor stages and regional lymph node metastasis in a large cohort of OSCC samples. The association between AEG-1 and distant metastasis was not statistically significant; evidence for an association may be confounded by the relatively low incidence $(10 \%)$ of distant metastasis at initial 


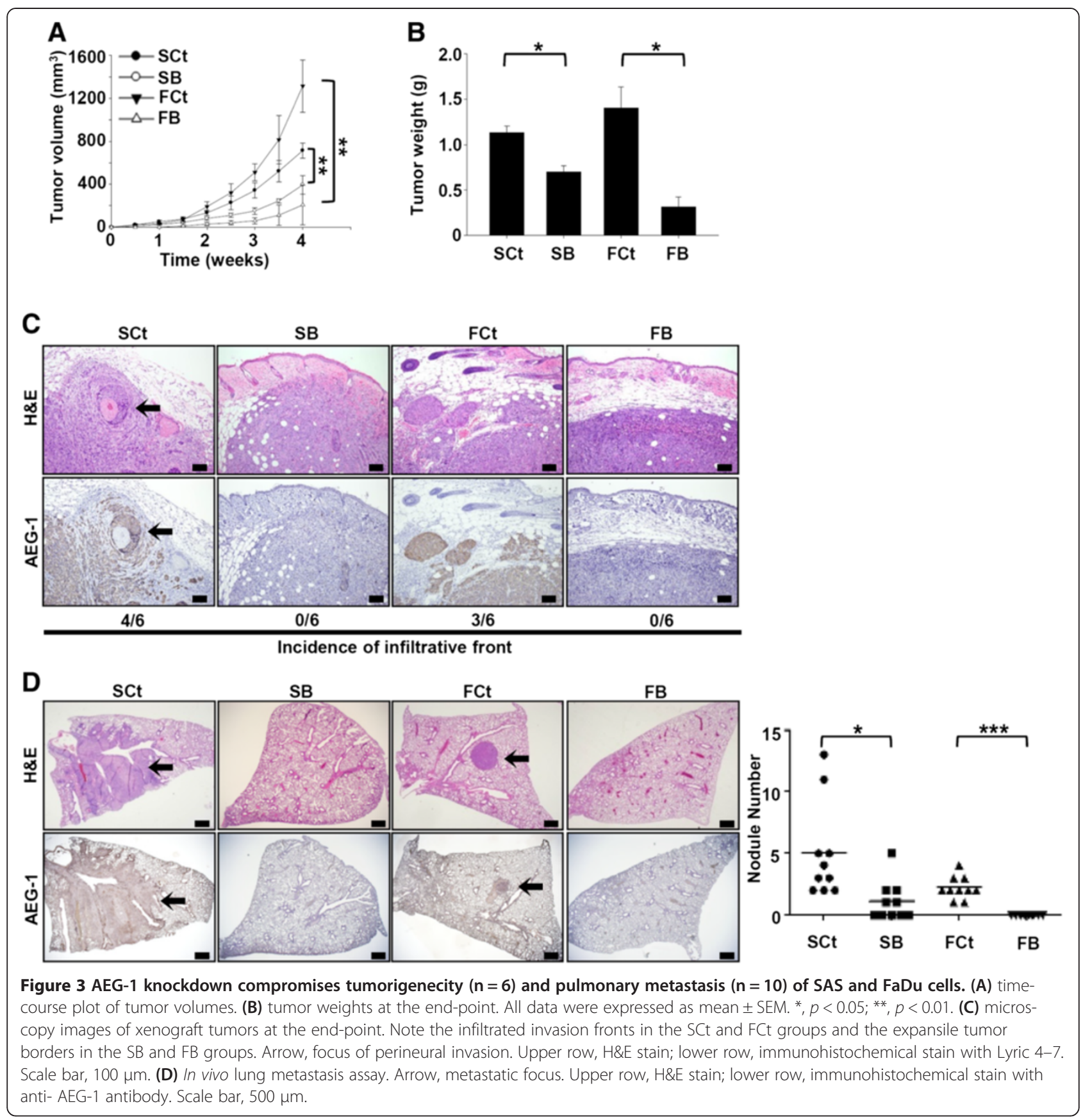

presentation, a feature intrinsic to HNSCC [23]. In addition, our research has demonstrated that silencing of AEG-1 mitigates the malignant phenotypes of HNSCC cell lines in vitro and attenuates tumor growth and pulmonary metastasis in vivo. Our results provide the first strong evidence that AEG-1 is overexpressed in at least a subset of HNSCC and contributes to adverse clinical outcomes. Moreover, we found that AEG-1 upregulates the expression of MMP1, thereby uncovering a novel mechanism underlying the invasiveness of HNSCC.
Metastasis, defined as the detachment of daughter cells from the primary site of lesions and subsequent colonization of preferential target organs, is one of the hallmarks of malignancies [24,25]. The metastasis cascade can be divided into steps of local invasion, intravasation, survival, extravasation and colonization. Degradation and remodeling of extracellular matrix (ECM) are essential for neoplastic permeation into adjacent stomal tissue, as well as for breaching the perivascular basement membrane to initiate metastasis. MMPs are zinc-dependent enzymes, consisting of a propeptide, 


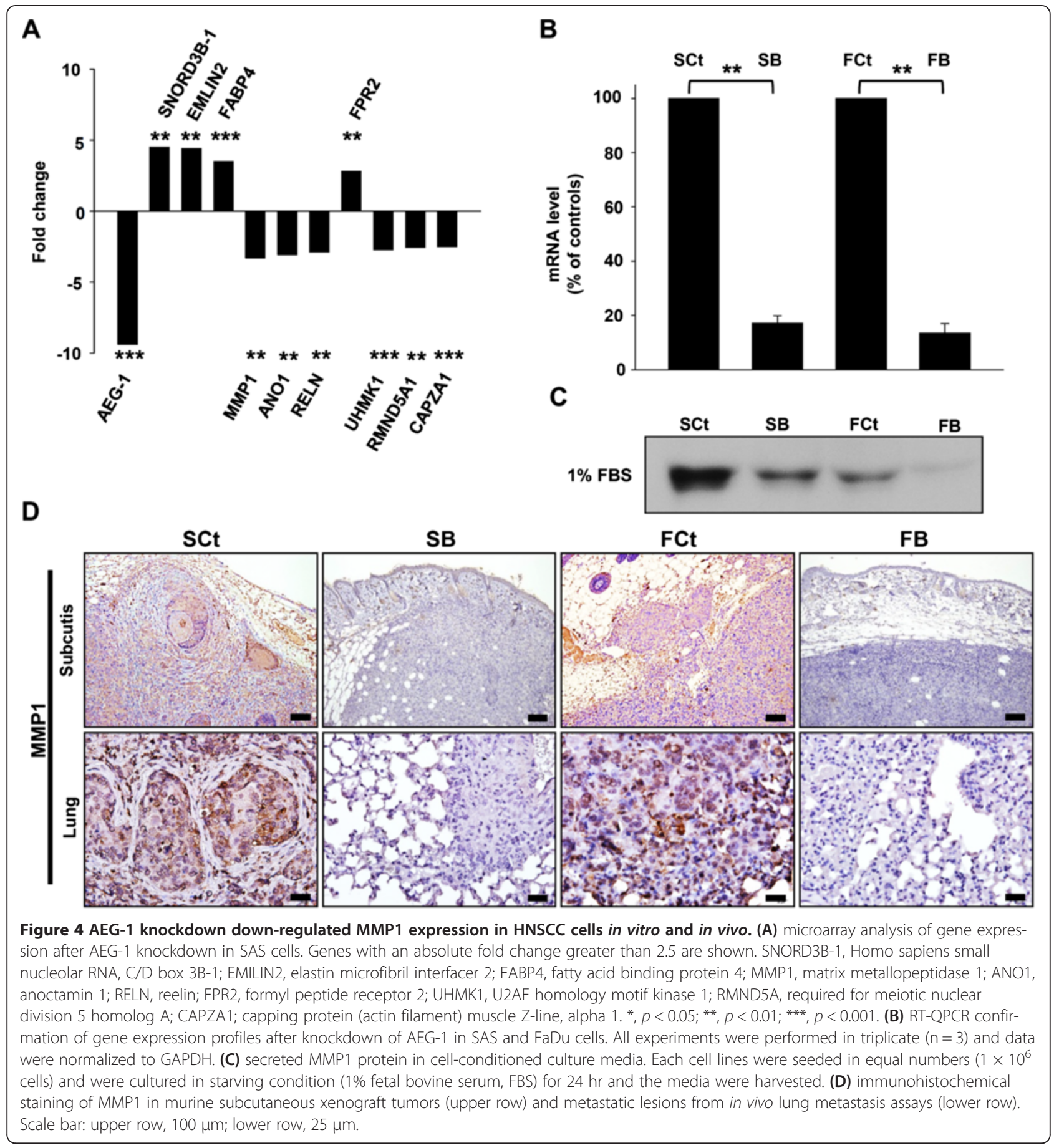

catalytic domain and a hemplexin-like $\mathrm{C}$ terminal domain. MMPs acquire enzymatic activity after peptidyl cleavage of the propeptide that interacts with the zinc ion in the catalytic domain [26]. The role of MMPs was traditionally believed to be primarily restricted to degradation of the ECM; however, mounting evidence suggests that MMPs are also involved in development, angiogenesis, inflammation and cancer progression, with the latter of which occurs through promoting migration and survival of cancer cells, orchestrating release of growth factors from extracellular reservoirs, and modulating recruitment of inflammatory cells to the tumor [27-29].

MMP1 is the stereotypical secreted collagenase of the MMP family, with its principle interstitial substrates consisting collagen I, II, III, VII, VIII, X, and gelatin. During collective cellular migration, which is the predominant pattern adopted by squamous cell carcinoma 


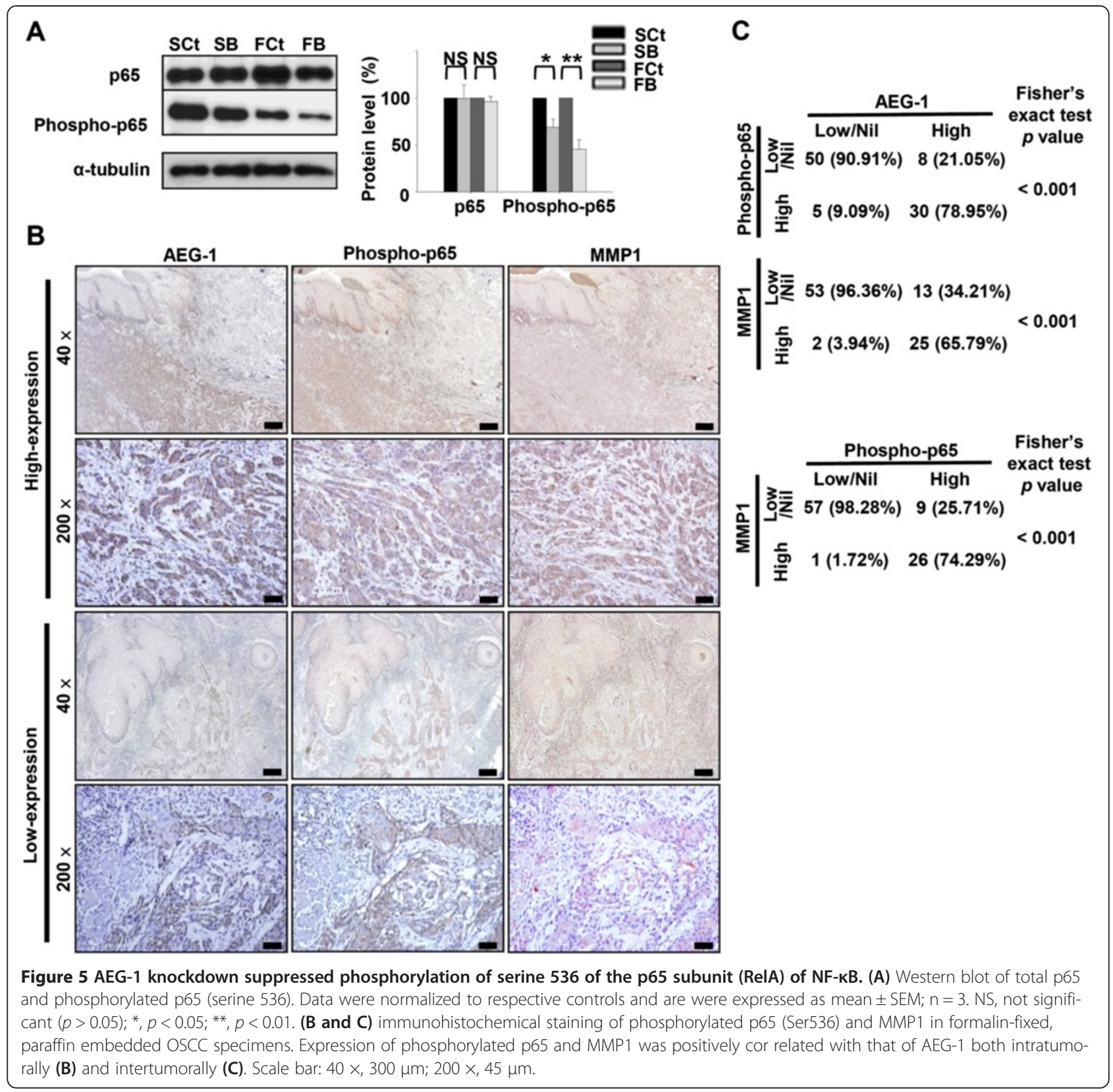

[30], MMP1 interacts with integrin $\alpha 2 \beta 1$ at the leading edge [31], and degrades native matrix macromolecules into fragments that are subsequently processed by the gelatinases MMP2 and MMP9 [32]. Analyses of clinical specimens revealed that expression of MMP1 correlated with lymphatic invasion and lymph node metastasis $[33,34]$. Furthermore, it is thought that MMP1 not only plays a pivotal role in vascular extravasation of metastatic neoplastic lesion, but it also contributes to the vascular remodeling at distant target sites, such as lung and bones [35-37]. Promotion of osteotropic metastasis can be accomplished in part by activation of the RANKL pathway through cleavage of EGF-like ligand by MMP1
[38]. In summary, MMP1 contributes to tumor invasion and metastasis by remodeling the matrix, and triggering the signaling cascades and crosstalk between neoplastic cells and adjacent interstitium. In our study, we have shown that AEG-1-knockdown SAS and FaDu cells reduce both the invasive ability of cancer cells (Figure 2D) and the expressions of MMP1 (Figure 4). Furthermore, MMP inhibitor is able to inhibit the invasive abilities of cancer cells (Additional file 3: Figure S2) to the level comparable to those observed in AEG-1-knockdown SAS and FaDu cells (Figure 2D). Taken together, these results indicate that AEG-1 is able to increase the invasive ability of cancer cells by increasing MMP1 expression. 

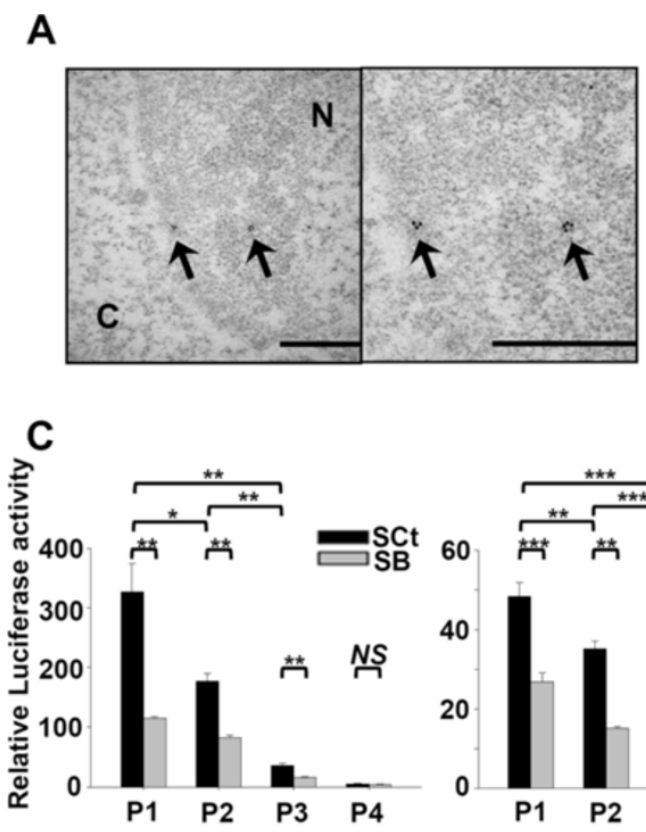

B

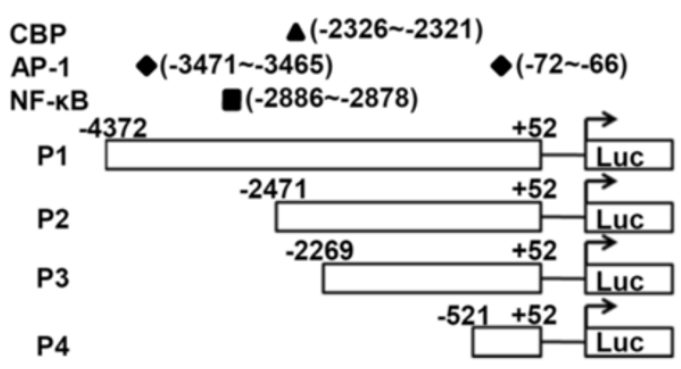

D

Figure 6 AEG-1 regulates MMP1 expression at the transcriptional level through enhancing the binding of p65 to MMP1 promoter. (A) nuclear translocation of AEG-1 protein was revealed by transmission electron microscopy. Arrow, $18 \mathrm{~nm}$ gold particles conjugated to antiAEG-1 antibody. N, nucleus. C, cytosol. Right, magnified view. Scale bar, $500 \mathrm{~nm}$. (B) constructs of the MMP1 promoter region used for the luciferase reporter assay. (C) transactivating activity of AEG-1 on MMP1 promoter constructs in the SAS and FaDu cell lines. All data were expressed as mean \pm SEM; $n=3$. (D) ChIP assay showing AEG-1, p65 and CBP binding to the NF-KB binding site of the MMP1 promoter in SAS and FaDu cell lines. NMIgG served as a negative control. All data were expressed as mean \pm SEM; $\mathrm{n}=3$. NS, not significant $(p>0.05) ;{ }^{*}, p<0.05 ;{ }^{*}, p<0.01$; ***, $p<0,001$.

To our knowledge, the present article is the first to report that AEG-1 regulates p65 phosphorylation at serine 536 and the subsequent MMP1 expression in HNSCC. MMP activity is modulated at various levels, including transcription, subcellular compartmentalization, proteolytic activation and inhibition. Data from our luciferase reporter assay indicate that AEG-1 regulates MMP1 transcription, primarily by acting on a region in the promoter upstream of nucleotide -2269 . Previous studies reported the presence of NF- $\mathrm{kB}$ and AP-1 binding sites at nucleotides -2886 and -3471 of the MMP1 promoter, respectively [39,40]. Although AEG-1 has previously been reported to regulate MMP9 expression [41] through c-jun in human glioma cells [18], we found that AEG-1 does not affect phosphorylation of serines 63 and 73 of c-jun. On the other hand, AEG-1 knockdown in HNSCC cell lines attenuated phosphorylation of the p65 subunit (RelA) of NF-kB at serine 536. Phosphorylation at this amino acid residue is required for perinuclear localization of p65 to facilitate nuclear import $[42,43]$. This observation was supported by the finding that AEG-1 expression correlates with phosphorylation of p65 at serine 536, both intertumorally and intratumorally, in OSCC clinical specimens $(p<0.001$, Fisher's exact test). It was thought that the activation of $N F-\kappa B$ requires degradation of IкB. However, post-translational modifications of the subunits of NF- $\mathrm{kB}$ have also been found to determine the functional activity to a great extent. Serine 536 of p65, which is located within the C-terminal transactivation domain, is a target of multiple protein kinases, including I $\mathrm{B}$ kinase $\alpha / \beta(\mathrm{IKK} \alpha / \beta)$, IKK $\varepsilon$, TANK binding kinase 1 (TBK1), and ribosomal S6 kinase 1 (RSK1). Phosphorylation at this amino acid residue has also been reported to suppress nuclear export of NF- $\mathrm{kB}$ and to increase transactivation of a variety of downstream genes through positive interaction of p65 with co-activators (CBP and p300) [44-48]. Phosphorylation of serine 536 also activates the survival-promoting pathway when cells are challenged with chemotherapeutic cytotoxic agents such as doxorubicin and etoposide [43,49].

As mentioned previously, AEG-1 contains no known functional domains, making it unlikely that AEG-1 phosphorylates p65 directly. Based on our findings, it seems plausible that AEG-1 enhances p65 phosphorylation by recruiting associated protein kinases to the AEG-1-p65 complex. More detailed experiments are required to confirm this hypothesis. Our ChIP data also revealed that AEG-1 enhances the binding of p65 to the MMP1 promoter, thereby activating downstream genes by functioning 
as a linker between p65 and CBP to form the basal transcriptional machinery. Although p65 has been suggested to bind to AEG-1 through amino acid residues 101 to 205 of the latter [16], the interacting regions of CBP and AEG-1 remain unknown. Elucidation of the exact binding epitopes will require examination of the crystal structure of AEG-1 and its associated proteins.

\section{Conclusion}

We used an extensive collection of HNSCC samples to demonstrate that elevated levels of AEG-1 protein are associated with lymph node metastasis and poor prognosis in HNSCC patients. AEG-1 primarily acts through the NF- $\mathrm{BB}$ pathway, by enhancing phosphorylation on serine 536 of RelA, which in turn results in an increased expression of MMP1. These findings may support the development of AEG-1-targeting therapeutics, such as small molecules, interference RNA with suitable drug delivering system or DNA vaccine, [50] to bolster our arsenal of adjuvant chemotherapy, and thereby improving the clinical outcome of HNSCC patients with high AEG1 expression. In the meantime, elucidation of physiological function of AEG-1 through transgenic murine models and large-scale screening of the expression status of AEG-1 in normal human tissue are required to minimize the potential side effect.

\section{Methods}

\section{Clinical specimen acquisition and clinicopathological staging}

Formalin-fixed, paraffin-embedded OSCC tissue blocks were retrieved (79 men and 14 women, mean age 53.9 years, range $25-82$ years) from the archive of the Department of Oral Pathology during 2000 to 2003, in accordance with ethical and institutional guidelines and with the approval of the Institutional Review Board of National Taiwan University Hospital (NTUH IRB, No 201111048RIC). Diagnosis of squamous cell carcinoma was based on histological examination of hematoxylin and eosin-stained (H\&E) tissue sections by two qualified oral pathologists (YP Wang and CP Chiang). The pathological stage of each case at the time of surgery was determined according to the $7^{\text {th }}$ edition of staging criteria from the American Joint Committee on Cancer. Also, specimens of oral mucosa from healthy volunteer donors with informed consent (30 cases) were collected as controls during the extractions of their impacted wisdom teeth. Tissue sections, which included both tumor and adjacent non-tumor parts for comparison purposes, were cut to $4 \mu \mathrm{m}$ in thickness.

\section{Immunohistochemical staining}

Sections were deparaffinized and rehydrated, and antigen retrieval was performed concomitantly in the
Trilogy buffer system (Cell Marque, Rocklin, CA, USA) in accordance with the manufacturer's instructions. Endogenous peroxidase activity was then blocked by immersing the sections with $3 \% \mathrm{H}_{2} \mathrm{O}_{2}$ in methanol for 30 minutes ( $\mathrm{min}$ ). After washing in phosphate-buffered saline (PBS), sections were incubated with $1 \%$ bovine serum albumin (BSA) for $30 \mathrm{~min}$ to block non-specific binding. Sections were then incubated with the monoclonal antibody Lyric 4-7 [51] at a concentration of $1 \mu \mathrm{g} / \mathrm{ml}$ for one hour at room temperature (RT). For staining of phosphorylated p65 and MMP1, antiphosphorylated p65 polyclonal antibody (sc-101753, Santa Cruz biotechnology, TX, USA) and anti-human MMP1 antibody (clone 36665, R\&D system, MN, USA) were used at a dilution of $1: 50$ and $15 \mu \mathrm{g} / \mathrm{ml}$, respectively. After being washed in PBS containing 0.1\% Tween $20\left(\mathrm{PBST}_{0.1}\right)$, sections were treated with the polymerbased Super Sensitive IHC detection system (Biogenex, San Ramon, CA). In brief, sections were incubated with Super Enhancer reagent for $20 \mathrm{~min}$ at RT and were then thoroughly rinsed three times with $\mathrm{PBST}_{0.1}$ for $5 \mathrm{~min}$ each. Sections were subsequently treated with Poly-HRP reagent for $30 \mathrm{~min}$ at $\mathrm{RT}$. Diaminobenzidine hydrochloride (DAB) $(0.02 \%)$ containing $0.03 \% \mathrm{H}_{2} \mathrm{O}_{2}$ was used as a chromogen to visualize peroxidase activity. The preparations were lightly counterstained with hematoxylin, mounted with Permount (Fisher Scientific, PA, USA), and examined by light microscopy. The population index (PI) was defined as: less than $10 \%$ positive tumor cells, 0 ; $10-49 \%$ positive tumor cells, 1 ; more than $50 \%$ positive tumor cells, 2. The intensity index (II) of the signal was designated as: none, 0 ; weak, 1; strong, 2 . The labeling score (LS) was the product of PI and II for each case. Samples were futher categorized as: LS $=0$, nil-expressing group; LS $=1$ or 2 , low-expressing group; and LS $=4$, high-expressing group. Tissue sections incubated with normal mouse IgG (NMIgG) instead of primary antibody were used as negative controls. All histopathological images were taken with an Olympus BX51 microscope and DP2-BSW image acquisition software.

\section{Cell lines}

OSCC cells lines HSC-3, SAS, and Ca9-22 were purchased from Japanese Collection of Research Bioresources Cell Bank and cell lines $\mathrm{Cal} 27$ (OSCC) and FaDu (pharyngeal squamous cell carcinoma) were purchased from American Type Culture Collection. All cell lines were cultured in recommended media and were used in less than 6 months after resucscitation. The authenticity of SAS and $\mathrm{FaDu}$ cell lines was confirmed by STR profiling at Bioresource Collection and Research Center (BCRC) (Taiwan). Stable AEG-1 knock-down clones of SAS and FaDu cells (SA to SE cells and FA to FE cells, respectively) were established through transfection with lentiviral vectors carrying various 
AEG-1-specific shRNA sequences from the National RNAi Core Facility of Academia Sinica. As controls, stable clones transfected with scrambled shRNA were generated for each cell line (SCt cells and FCt cells, respectively). Stable clones were selected by treatment of the cells with $2 \mu \mathrm{g} / \mathrm{ml}$ puromycin for 14 days. Knockdown efficiency was determined by measuring mRNA and protein by real-time quantitative polymerase chain reaction (RT-QPCR) and Western blot, respectively (Additional file 2: Figure S1A and B).

\section{Western blot analysis}

Western blots were performed using standard protocols, as previously described [51]. Total cell protein lysates of the indicated cell lines were loaded onto polyacrylamide gels supplemented with SDS (40 $\mu \mathrm{g}$ /lane). The following primary antibodies were used at the indicated concentrations: Lyric 4-7, $0.5 \mu \mathrm{g} / \mathrm{ml}$; $\alpha$-tubulin (Sigma-Aldrich Corporation, MO,USA), 5000-fold dilution; and MMP1 (clone 36665, R\&D system, MN, USA), $1 \mu \mathrm{g} / \mathrm{ml}$. Antibodies against the following proteins were purchased from Cell Signaling Technology (Danvers, MA, USA) and were used at a 1000-fold dilution: NF-kB (E498), phospho-NF-kB p65 (Ser536) (93H1), and phospho-NFкB p65 (Ser468) (\#3039).

\section{In vivo xenograft tumor assays}

$\mathrm{SCt}, \mathrm{SB}, \mathrm{FCt}$ and FB cells were subcutaneously inoculated in pairs into the flanks of 6-week-old Nod/SCID mice $\left(1 \times 10^{6}\right.$ cells/mouse, $\mathrm{n}=6$ per group). Laboratory animal husbandry and in vivo experiments were performed as per the guidelines of the National Laboratory Animal Center. The diameter of the resulting tumors were measured twice per week, and tumor volume was calculated as follows: large diameter $\times(\text { small diameter })^{2} \times 0.52$. Xenograft tumors were harvested at the end point of the experiment and were sent for routine tissue processing.

\section{In vivo pulmonary metastasis assay}

SCt, SB, FCt and FB cells were intravenously injected into six-week-old Nod/SCID mice $\left(2 \times 10^{5}\right.$ cells/mouse, $\mathrm{n}=10$ per group) through the tail vein. All lung lobes were harvested twelve weeks later. Routine tissue processing was subsequently performed, and pulmonary metastatic foci were counted in sections stained with H\&E.

\section{Microarray analysis}

Total RNAs from SCt and SB cells were extracted and sent to the Microarray Core Facility of the Institute of Molecular Biology, Academia Sinica. The reversetranscripted DNA probes were coupled with Alexa/ CyDye and were hybridized with an Agilent human V2 GX array $(44 \mathrm{~K} \times 4)$. The fluorescence of the array was scanned and analyzed, and the raw data were uploaded into the GEO data base as GSE 44766. Genes with a greater than 2.5 fold change (FC) in expression were then recorded (details in the Additional file 7: Supplementary Materials and Methods).

\section{Real-time quantitative polymerase chain reaction}

Total RNA was extracted from SCt, SB, FCt and FB cells, and reverse transcription was subsequently performed. RT-QPCR was conducted using SYBR Green and the LightCycler480 II System (Roche Applied Science, Indianapolis, IN, USA). Each reaction was performed in triplicate (details in the Additional file 7: Supplementary Materials and Methods).

\section{Immunogold labeling and transmission electron microscopy}

SAS cells were harvested and sent to the Electron Microscope Core Facility of the Institute of Cellular and Organismic Biology, Academia Sinica. Primary antibody against LYRIC (or NMIgG for negative controls) was applied at a concentration of $0.5 \mu \mathrm{g} / \mathrm{ml}$ for 1 hour at RT. The sections were examined with a transmission electron microscope (Hitachi H-7000) (details in the Additional file 7: Supplementary Materials and Methods).

\section{Luciferase assay of the MMP1 promoter region}

The full length promoter region of the MMP1 gene [40] was cloned from of SAS cell genomic DNA using KAPA HiFi DNA polymerase with the following primers: CCCCTCGAGAGATGTAAGAGCTGGGAAAGGACGG (forward) and CCCAAGCTTTCAGTGCAAGGTAAGT GATGGCTTC (reverse). To generate a truncated fragment without the NF- $\kappa B$ binding site, the following primers were used: CCCCTCGAGCGATCTTCCATGA ATACCTAACTGG (forward) and CCCAAGCTTTCAG TGCAAGGTAAGTGATGGCTTC (reverse). The cloned full length or truncated MMP1 promoters (nucleotides -2471 to +52 ) and luciferase reporter vector pGL4 (Promega, Madison, WI, USA) were digested with Xho I and HindIII. The full length or truncated promoter sequence was then ligated into pGL4 with T4 ligase at $16^{\circ} \mathrm{C}$ overnight. The resulting reporter vectors were designated as P1 $(-4372$ to +52$)$ and P2 $(-2471$ to +52$)$. Reporter vectors P3 (containing nucleotides -2269 to +52 ) and $\mathrm{P} 4$ (containing nucleotides -521 to +52 ) were generated by digesting the truncated MMP1 promoter either with SacI and HindIII or KpnI and HindIII, respectively, before ligating it into pGL4. Cells (SCt, SB, FCt and FB) were seeded onto 24 -well plates $\left(1 \times 10^{5}\right.$ cells/well $)$ and were incubated at $37^{\circ} \mathrm{C}$ for 24 hours. The culture media was refreshed, and transfection with a reporter vector (one of P1 to P4) together with pGL4 (400 ng) and control Renilla vector (100 ng) was performed $30 \mathrm{~min}$ later, using Genejet (SignaGen laboratories, Rockville, 
MD) as per the manufacturer's protocol. Firefly luciferase and Renilla readouts were acquired 18 hours posttransfection using the Dual-Glo Luciferase Assay System (Promega, Madison, WI, USA) according to the manufacturer's recommendations.

\section{Chromatin immunoprecipitation (ChIP) assay}

ChIP assay was performed with the Magna ChIP ${ }^{\text {rix }} \mathrm{G}$ kit (Millipore, Billerica, MA, USA) in accordance with the manufacturer's protocol. In brief, $1 \times 10^{7}$ cells were fixed with $1 \%$ paraformaldehyde and were lysed with cell lysis buffer and nuclear lysis buffer supplemented with protease cocktail inhibitors. Lysates were sonicated to shear the crosslinked DNA to a size of 200-1000 base pairs. Equal amounts of sheared cross-linked DNA were incubated at $4^{\circ} \mathrm{C}$ overnight on a shaker, with protein $\mathrm{G}$ magnetic beads coupled to either Lyric 4-7, anti-p65 antibody (L8F6, Cell Signaling, Danvers, MA, USA), anti-CREB binding protein (CBP) antibody (D9B6, Cell Signaling, Danvers, MA, USA) or NMIgG (as a negative control). The captured DNA-protein complexes were dissociated with elution buffer and proteinase $\mathrm{K}$ at $62^{\circ} \mathrm{C}$ for 2 hours with shaking. The free DNA fragments were then purified and quantified by RT-QPCR using primers $(50 \mu \mathrm{M})$ flanking the p65 binding site (forward, GAGTTACAAAATTAAAACGGCTGA and reverse, CT GGCTGCTCTGTGAAAG). SYBR fluorescence was measured with a Lightcycler 480 II (Roche Applied Science, Indianapolis, IN, USA).

\section{Statistical analysis}

The associations between clinicopathological parameters and the expression status of AEG-1, phosphorylated p65, and MMP1 within clinical specimens were analyzed by Fisher's exact test. Disease-specific survival was compared between groups by Kaplan-Meier culmulative survival analysis with log-rank tests. All in vitro comparisons between HNSCC cells transfected with control shRNA and their experimental counterparts were performed with 3 technical replicates and 3 independent biological replicates $(\mathrm{n}=3)$. Data analyses of in vitro experiments were performed by $t$-test. A $p$-value of less than 0.05 was considered statistically significant for all tests.

\section{Additional files}

Additional file 1: Table S1. Correlation of advanced lymph node metastasis with AEG-1 in 93 cases of OSCC.

Additional file 2: Figure S1. Establishment of stable clones of AEG-1knockdown HNSCC cell lines. A, upper, sequences of shRNA targeting to AEG-1 mRNA; lower, AEG-1 protein expression in SAS cells after transfection of shRNA. B, Western blotting of total cell lysates from both cell lines transfected with lentiviral AEG-1-specific shRNA showed efficient AEG-1 suppression in protein level in SAS and FaDu cells $(1.65 \%$ and $14.16 \%$ respectively, normalized with the expression levels of a-tubulin).
Additional file 3: Figure S2. MMP inhibitor I (MMPInhl, $2 \mu \mathrm{M})$ impeded invasion of SAS and FaDu cells into Matrigel All values are the average of three independent experiments. ${ }^{* *}, p<0.001 ;{ }^{* *}, p<0.01$. Scale Bar: $130 \mu \mathrm{m}$.

Additional file 4: Figure S3. The phosphorylated status of components in PI3K pathway and NFKB pathway. A, c-jun and downstream effectors of PI3K pathway. B, IKB and $p 65$ at amino acid residue serine 468.

Additional file 5: Table S2. Clinicopathological correlation with phosphorylated p65 (serine 536) in 93 cases of OSCC.

Additional file 6: Table S3. Clinicopathological correlation with MMP1 in 93 cases of OSCC.

Additional file 7: Supplementary Materials and Methods.

Competing interest

The authors declare that they have no competing interest.

\section{Authors' contributions}

Conception and design: HCW and YPW. Development of methodology: YPW and IJL. Acquisition of data: YPW and IJL. Analysis and interpretation of data: YPW, IJL and CPC. Writing, review and/or revision of the manuscript: YPW and HCW. Administrative, technical, or material support: HCW. Study supervision: HCW. All authors read and approved the final manuscript.

\section{Acknowledgements}

We thank the Core Facility of the Institute of Cellular and Organismic Biology, the Microarray Core Facility of the Institute of Molecular Biology, and the National RNAi Core Facility, Academia Sinica for their generous and proficient technical support.

Funding

The current study was supported by the National Science Council, Taiwan, Grants NSC101-2325-B-001-010 and NSC101-2321-B-001-021 (to Han-Chung Wu), start-up funding for new faculty, National Taiwan university, Taipei, Taiwan, No.98R0616 and Professor Kwan's foundation, Taipei, Taiwan (to Yi-Ping Wang).

\section{Author details}

${ }^{1}$ Graduate Institute of Clinical Dentistry, School of Dentistry, National Taiwan University, Taipei, Taiwan. ${ }^{2}$ Institute of Cellular and Organismic Biology, Academia Sinica, Taipei, Taiwan. ${ }^{3}$ Department of Dentistry, National Taiwan University Hospital, Taipei, Taiwan. ${ }^{4}$ Graduate Institute of Oral Biology, School of Dentistry, National Taiwan University, Taipei, Taiwan.

Received: 3 July 2013 Accepted: 17 September 2013

Published: 24 September 2013

\section{References}

1. Jemal A, Bray F, Center MM, Ferlay J, Ward E, Forman D: Global cancer statistics. CA Cancer J Clin 2011, 61:69-90.

2. Leemans CR, Tiwari R, Nauta JJ, van der Waal I, Snow GB: Regional lymph node involvement and its significance in the development of distant metastases in head and neck carcinoma. Cancer 1993, 71:452-456.

3. Karamouzis MV, Grandis JR, Argiris A: Therapies directed against epidermal growth factor receptor in aerodigestive carcinomas. JAMA 2007, 298:70-82

4. Burtness B, Goldwasser MA, Flood W, Mattar B, Forastiere AA: Phase III randomized trial of cisplatin plus placebo compared with cisplatin plus cetuximab in metastatic/recurrent head and neck cancer: an Eastern Cooperative Oncology Group study. J Clin Oncol 2005, 23:8646-8654.

5. Vermorken JB, Trigo J, Hitt R, Koralewski P, Diaz-Rubio E, Rolland F, Knecht R, Amellal N, Schueler A, Baselga J: Open-label, uncontrolled, multicenter phase II study to evaluate the efficacy and toxicity of cetuximab as a single agent in patients with recurrent and/or metastatic squamous cell carcinoma of the head and neck who failed to respond to platinumbased therapy. J Clin Oncol 2007, 25:2171-2177.

6. Emdad L, Sarkar D, Su ZZ, Randolph A, Boukerche H, Valerie K, Fisher PB: Activation of the nuclear factor kappaB pathway by astrocyte elevated gene-1: implications for tumor progression and metastasis. Cancer Res 2006, 66:1509-1516.

7. Kikuno N, Shiina H, Urakami S, Kawamoto K, Hirata H, Tanaka Y, Place RF, Pookot D, Majid S, Igawa M, Dahiya R: Knockdown of astrocyte-elevated 
gene-1 inhibits prostate cancer progression through upregulation of FOXO3a activity. Oncogene 2007, 26:7647-7655.

8. Li J, Zhang N, Song LB, Liao WT, Jiang LL, Gong LY, Wu J, Yuan J, Zhang $H Z$, Zeng MS, Li M: Astrocyte elevated gene-1 is a novel prognostic marker for breast cancer progression and overall patient survival. Clin Cancer Res 2008, 14:3319-3326.

9. Hu G, Chong RA, Yang Q, Wei Y, Blanco MA, Li F, Reiss M, Au JL, Haffty BG, Kang Y: MTDH activation by 8 q22 genomic gain promotes chemoresistance and metastasis of poor-prognosis breast cancer. Cancer Cell 2009, 15:9-20.

10. Song L, Li W, Zhang H, Liao W, Dai T, Yu C, Ding X, Zhang L, Li J: Overexpression of AEG-1 significantly associates with tumour aggressiveness and poor prognosis in human non-small cell lung cancer. J Pathol 2009, 219:317-326.

11. Yoo BK, Emdad L, Su ZZ, Villanueva A, Chiang DY, Mukhopadhyay ND, Mills AS, Waxman S, Fisher RA, Llovet JM, et al: Astrocyte elevated gene-1 regulates hepatocellular carcinoma development and progression. J Clin Invest 2009, 119:465-477.

12. Li J, Yang L, Song L, Xiong H, Wang L, Yan X, Yuan J, Wu J, Li M: Astrocyte elevated gene- 1 is a proliferation promoter in breast cancer via suppressing transcriptional factor FOXO1. Oncogene 2009, 28:3188-3196.

13. Hui AB, Bruce JP, Alajez NM, Shi W, Yue S, Perez-Ordonez B, Xu W, O'Sullivan $B$, Waldron J, Cummings B, et al: Significance of dysregulated metadherin and microRNA-375 in head and neck cancer. Clin Cancer Res 2011, $17: 7539-7550$.

14. Thirkettle HJ, Girling J, Warren AY, Mills IG, Sahadevan K, Leung H, Hamdy F, Whitaker HC, Neal DE: LYRIC/AEG-1 is targeted to different subcellular compartments by ubiquitinylation and intrinsic nuclear localization signals. Clin Cancer Res 2009, 15:3003-3013.

15. Brown DM, Ruoslahti E: Metadherin, a cell surface protein in breast tumors that mediates lung metastasis. Cancer Cell 2004, 5:365-374.

16. Sarkar D, Park ES, Emdad L, Lee SG, Su ZZ, Fisher PB: Molecular basis of nuclear factor-kappaB activation by astrocyte elevated gene-1. Cancer Res 2008, 68:1478-1484.

17. Lee SG, Su ZZ, Emdad L, Sarkar D, Franke TF, Fisher PB: Astrocyte elevated gene-1 activates cell survival pathways through PI3K-Akt signaling. Oncogene 2008, 27:1114-1121.

18. Liu L, Wu J, Ying Z, Chen B, Han A, Liang Y, Song L, Yuan J, Li J, Li M: Astrocyte elevated gene-1 upregulates matrix metalloproteinase- 9 and induces human glioma invasion. Cancer Res 2010, 70:3750-3759.

19. Yoo BK, Santhekadur PK, Gredler R, Chen D, Emdad L, Bhutia S, Pannell L, Fisher PB, Sarkar D: Increased RNA-induced silencing complex (RISC) activity contributes to hepatocellular carcinoma. Hepatology 2011, 53:1538-1548.

20. Blanco MA, Aleckovic M, Hua Y, Li T, Wei Y, Xu Z, Cristea IM, Kang Y: Identification of staphylococcal nuclease domain-containing 1 (SND1) as a Metadherin-interacting protein with metastasis-promoting functions. J Biol Chem 2011, 286:19982-19992.

21. He XX, Chang Y, Meng FY, Wang MY, Xie QH, Tang F, Li PY, Song YH, Lin JS: MicroRNA-375 targets AEG-1 in hepatocellular carcinoma and suppresses liver cancer cell growth in vitro and in vivo. Oncogene 2012, 31:3357-3369.

22. Nohata N, Hanazawa T, Kikkawa N, Mutallip M, Sakurai D, Fujimura L, Kawakami K, Chiyomaru T, Yoshino H, Enokida H, et al: Tumor suppressive microRNA-375 regulates oncogene AEG-1/MTDH in head and neck squamous cell carcinoma (HNSCC). J Hum Genet 2011, 56:595-601.

23. Argiris A, Karamouzis MV, Raben D, Ferris RL: Head and neck cancer. Lancet 2008, 371:1695-1709.

24. Gupta GP, Massague J: Cancer metastasis: building a framework. Cell 2006, 127:679-695.

25. Steeg PS: Tumor metastasis: mechanistic insights and clinical challenges. Nat Med 2006, 12:895-904.

26. Gross J, Lapiere CM: Collagenolytic activity in amphibian tissues: a tissue culture assay. Proc Natl Acad Sci U S A 1962, 48:1014-1022.

27. Boire A, Covic L, Agarwal A, Jacques $S$, Sherifi $S$, Kuliopulos A: PAR1 is a matrix metalloprotease-1 receptor that promotes invasion and tumorigenesis of breast cancer cells. Cell 2005, 120:303-313.

28. Yu Q, Stamenkovic I: Cell surface-localized matrix metalloproteinase-9 proteolytically activates TGF-beta and promotes tumor invasion and angiogenesis. Genes Dev 2000, 14:163-176.
29. McQuibban GA, Gong JH, Wong JP, Wallace JL, Clark-Lewis I, Overall CM: Matrix metalloproteinase processing of monocyte chemoattractant proteins generates CC chemokine receptor antagonists with antiinflammatory properties in vivo. Blood 2002, 100:1160-1167.

30. Friedl P, Noble PB, Walton PA, Laird DW, Chauvin PJ, Tabah RJ, Black M, Zanker KS: Migration of coordinated cell clusters in mesenchymal and epithelial cancer explants in vitro. Cancer Res 1995, 55:4557-4560.

31. Dumin JA, Dickeson SK, Stricker TP, Bhattacharyya-Pakrasi M, Roby JD, Santoro SA, Parks WC: Pro-collagenase-1 (matrix metalloproteinase-1) binds the alpha(2)beta(1) integrin upon release from keratinocytes migrating on type I collagen. J Biol Chem 2001, 276:29368-29374.

32. Deryugina El, Bourdon MA, Reisfeld RA, Strongin A: Remodeling of collagen matrix by human tumor cells requires activation and cell surface association of matrix metalloproteinase-2. Cancer Res 1998, 58:3743-3750.

33. Langenskiold M, Holmdahl L, Falk P, Ivarsson ML: Increased plasma MMP-2 protein expression in lymph node-positive patients with colorectal cancer. Int J Colorectal Dis 2005, 20:245-252.

34. Baker EA, Bergin FG, Leaper DJ: Matrix metalloproteinases, their tissue inhibitors and colorectal cancer staging. Br J Surg 2000, 87:1215-1221.

35. Minn AJ, Gupta GP, Siegel PM, Bos PD, Shu W, Giri DD, Viale A, Olshen AB, Gerald WL, Massague J: Genes that mediate breast cancer metastasis to lung. Nature 2005, 436:518-524.

36. Gupta GP, Nguyen DX, Chiang AC, Bos PD, Kim JY, Nadal C, Gomis RR, Manova-Todorova K, Massague J: Mediators of vascular remodelling coopted for sequential steps in lung metastasis. Nature 2007, 446:765-770.

37. Kang Y, Siegel PM, Shu W, Drobnjak M, Kakonen SM, Cordon-Cardo C, Guise TA, Massague J: A multigenic program mediating breast cancer metastasis to bone. Cancer Cell 2003, 3:537-549.

38. Lu X, Wang Q, Hu G, Van Poznak C, Fleisher M, Reiss M, Massague J, Kang Y: ADAMTS1 and MMP1 proteolytically engage EGF-like ligands in an osteolytic signaling cascade for bone metastasis. Genes Dev 2009, 23:1882-1894.

39. Maldonado A, Game BA, Song L, Huang Y: Up-regulation of matrix metalloproteinase-1 expression in U937 cells by low-density lipoproteincontaining immune complexes requires the activator protein-1 and the Ets motifs in the distal and the proximal promoter regions. Immunology 2003, 109:572-579.

40. Rutter JL, Benbow U, Coon Cl, Brinckerhoff CE: Cell-type specific regulation of human interstitial collagenase-1 gene expression by interleukin-1 beta (IL-1 beta) in human fibroblasts and BC-8701 breast cancer cells. J Cell Biochem 1997, 66:322-336.

41. Emdad L, Sarkar D, Lee SG, Su ZZ, Yoo BK, Dash R, Yacoub A, Fuller CE, Shah $K$, Dent $P$, et al: Astrocyte elevated gene-1: a novel target for human glioma therapy. Mol Cancer Ther 2010, 9:79-88.

42. Moreno R, Sobotzik JM, Schultz C, Schmitz ML: Specification of the NF-kappaB transcriptional response by $\mathrm{p} 65$ phosphorylation and TNF-induced nuclear translocation of IKK epsilon. Nucleic Acids Res 2010, 38:6029-6044.

43. Bohuslav J, Chen LF, Kwon H, Mu Y, Greene WC: p53 induces NF-kappaB activation by an IkappaB kinase-independent mechanism involving phosphorylation of p65 by ribosomal S6 kinase 1. J Biol Chem 2004, 279:26115-26125.

44. Sakurai H, Chiba H, Miyoshi H, Sugita T, Toriumi W: IkappaB kinases phosphorylate NF-kappaB p65 subunit on serine 536 in the transactivation domain. J Biol Chem 1999, 274:30353-30356.

45. O'Mahony AM, Montano M, Van Beneden K, Chen LF, Greene WC: Human T-cell lymphotropic virus type 1 tax induction of biologically Active NF-kappaB requires IkappaB kinase-1-mediated phosphorylation of RelA/p65. J Biol Chem 2004, 279:18137-18145.

46. Jiang X, Takahashi N, Matsui N, Tetsuka T, Okamoto T: The NF-kappa B activation in lymphotoxin beta receptor signaling depends on the phosphorylation of p65 at serine 536. J Biol Chem 2003, 278:919-926.

47. Buss H, Dorrie A, Schmitz ML, Hoffmann E, Resch K, Kracht M: Constitutive and interleukin-1-inducible phosphorylation of p65 NF-KB at serine 536 is mediated by multiple protein kinases including IKB kinase IKKa, IKK IKKE, TRAF family member-associated (TANK)-binding kinase 1 (TBK1), and an unknown kinase and couples p65 to TATA-binding proteinassociated factor II31-mediated interleukin-8 transcription. J Biol Chem 2004, 279:55633-55643. 
48. Fujita F, Taniguchi Y, Kato T, Narita Y, Furuya A, Ogawa T, Sakurai H, Joh T, Itoh M, Delhase M, et al: Identification of NAP1, a regulatory subunit of IkappaB kinase-related kinases that potentiates NF-kappaB signaling. Mol Cell Biol 2003, 23:7780-7793.

49. Ho WC, Dickson KM, Barker PA: Nuclear factor-kappaB induced by doxorubicin is deficient in phosphorylation and acetylation and represses nuclear factor-kappaB-dependent transcription in cancer cells. Cancer Res 2005, 65:4273-4281.

50. Qian BJ, Yan F, Li N, Liu QL, Lin YH, Liu CM, Luo YP, Guo F, Li HZ: MTDH/ AEG-1-based DNA vaccine suppresses lung metastasis and enhances chemosensitivity to doxorubicin in breast cancer. Cancer Immunol Immunother 2011, 60:883-893.

51. Liu IJ, Chiu CY, Chen YC, Wu HC: Molecular mimicry of human endothelial cell antigen by autoantibodies to nonstructural protein 1 of dengue virus. J Biol Chem 2011, 286:9726-9736.

doi:10.1186/1476-4598-12-109

Cite this article as: Wang et al:: Astrocyte elevated gene-1 is associated with metastasis in head and neck squamous cell carcinoma through p65 phosphorylation and upregulation of MMP1. Molecular Cancer 2013 12:109.

\section{Submit your next manuscript to BioMed Central and take full advantage of:}

- Convenient online submission

- Thorough peer review

- No space constraints or color figure charges

- Immediate publication on acceptance

- Inclusion in PubMed, CAS, Scopus and Google Scholar

- Research which is freely available for redistribution 